Effect of Extracts of Eruca sativa Mill. on the Growth Inhibition of Some Fungal Species

Sirwan Hassan Salih and Mostafa Qahtan Mosataf

\title{
Effect of Extracts of Eruca sativa Mill. on the Growth Inhibition of Some Fungal Species
}

\author{
Sirwan Hassan Salih* and Mostafa Qahtan Mosataf ** \\ *Biology Dept. College of Education- University of Garmian \\ **Bology Dept. College of Education -University of Tikret
}

Received 5 June 2016; Accepted 9 October 2016

\begin{abstract}
$\underline{\text { Abstract }}$
This study was carried out to show the effect of extracts (aqueous, alkaloid and glycosides) of Eruca sativa Mill. on the fungal growth, the results revealed the inhibitory effectiveness of the aqueous, alcoholic and glycosides extracts of $E$. sativa by four different concentrations (10\%, $20 \%, 40 \%$ and $100 \% \mathrm{mg} / \mathrm{ml}$ ) on the growth of three fungal species in three different genera (Aspergillus niger, Fusarium oxysporium and Pencellium sp.). The results showed that these concentrations of the aqueous extracts have an impact on inhibiting the growth of two fungal species (Pencellium sp. and F. oxysporium) variously, while the same concentrations of aqueous extracts did not affect on the growth of $A$. niger as well as it showed the ineffectiveness of various concentrations of alcoholic extracts in the inhibition of these fungi, whereas it was appeared the effectiveness of the same concentrations of glycoside extracts in the inhibition of two fungi $F$. oxysporium and Penceillium sp differently, whilst the same concentrations did not inhibit the growth of A. nigar
\end{abstract}

Key words: Phytochemical, extracts effectiveness, Eruca sativa 
Effect of Extracts of Eruca sativa Mill. on the Growth Inhibition of Some Fungal Species

Sirwan Hassan Salih and Mostafa Qahtan Mosataf

\author{
تأثثر مستخلصات نبات الجرجير . Eruca sativa Mill في تثبط نمو بعض الفطريات \\ سيروان حسن صالح" و مصطفى قحطان مصطقى ** \\ "كلية التربية- علوم الحياة - جامعة كرمبان

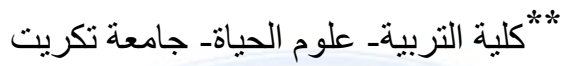

\title{
الخلاصة
}

هدفت الدر اسة الحالية الى معرفة الفعالية التثبيطية للمستخلصات المائية و الكحولية و الكلايكوسيدية لنبات الجرجير Eruca , Pencillium sp وبتر اكيز مختلفة (10, 20, 40 و 100 ملغم/مل ) تجاه ثنلاث انواع من الفطريات هي هي . Aspergillus nigar و Fusarium oxysporium , الكلايكوسيدي بتراكيزه المختلفة في تثبيط الانواع الفطرية المدروسة، حيث اثر المستخلص المائي في تثبيط الفطرين F. oxysporium و Pencillium sp

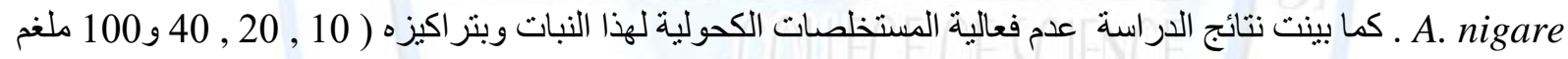
/ مل) في تثبط الفطريات المدروسة بينما اثرت المستخلصات الكلايكوسيدية للنبات وبتر اكيز ها الاربعة في تثبيط نمو A. nigare بينما لم تؤثر نفس التراكيز في نمو النوع F. oxysporium و Pencillium sp الفطرين Eruca sativa الكلمات المفتاحية: كيمياء النبات، فعالية المستخلصات ، نبات الجرجير

\section{Introduction}

The species Eruca sativa (Arugula) is an herbaceous annual plant of the family Brassicaceae which is a large family comprises about 365 genera and 3200 species all over the world (APG III, 2009). With widespread be cultivated or wild, plant seeds contain glycosides, alkaloids, volatile oils, vitamin C, Iodine, Iron sulphate and Calcium (Evans, 1999; Hussein, 1985 and Kochhar, 1981). This plant has therapeutic and medical importance that uses in Dermatitis treatment, boils, burns, indigestion, tuberculosis, gingivitis and alopecia (Roiha, 


\section{Effect of Extracts of Eruca sativa Mill. on the Growth Inhibition of} Some Fungal Species

\section{Sirwan Hassan Salih and Mostafa Qahtan Mosataf}

1983). Jamba oil was extracted from the seeds that is useful for humans, which is used in many industries including industry of soaps, shampoos for hair loss, cosmetics, food appetizers, massage oil and the production of bio-fuel (Mohammed and Rafiq, 2009). Arugulas oil has medical effectiveness include improving liver function and a reduced rate of blood sugar (ElGengaihi et al., 2004), improve the effectiveness of sex hormones (Merza et al., 2000) and an anti-bacterial and fungi (Abdou et al., 2005) also the oil used in a Biological control against of many pests (Yaniv, 1997). Some of the extracted oils are rich in sulphate compounds that characterized by its ability to kill microbes also the existence of glucosinolates compounds which has biological activities against microorganisms (Holt et al, 1994).

Due to the importance of the chemical compounds in this species, this study aimed to know the inhibitory effectiveness of $E$. sativa extracts in the inhibition of some fungal species.

\section{Materials and methods}

Plant specimens were collected from cultivated orchards during spring season. Some specimens were pressed and dried for diagnosis, tagged and deposited in the herbarium of the Biology department. Other selected specimens were cleaned from the dust and impurities and then rinsed with the water then dried at room temperature away from the light to avoid oxidation. After drying the plant specimens has been grinding by using laboratory electric mill and then placed in opaque plastic cans finally stored refrigerated until extraction.

\section{Hot Aqueous Extraction:}

According to (Al- Joboory and Al-Rawi , 1994) the hot water extraction was conducted by mixing 40mg of specimen with the $160 \mathrm{ml}$ of distilled water (rate 1:4 weight: size) (overheating 95-100 $\mathrm{C}^{\circ}$ ) twice with shaking the mixture to break down plant cell walls and leave it in the refrigerator for 24 hours for the soaking. Mixture was filtrated through several layers of medical gauze, and filtrated once again by Buchner funnel using watman papers No.1 to get rid of the non-crushed parts and fibers to obtain plant extract raw liquid which put them in a Rotary vacuum evaporator at the temperature of not more than $40^{\circ}$ as it works on the basis evaporation under rarefied pressure. Extracted output was placed in Shaker incubator at a temperature of $30-35^{\circ}$. Dried extract was saved freeze in airtight containers and labeled until in use. 
Effect of Extracts of Eruca sativa Mill. on the Growth Inhibition of Some Fungal Species

\section{Sirwan Hassan Salih and Mostafa Qahtan Mosataf}

\section{Ethanolic Extraction:}

The ethanolic extraction was prepared by mixing $20 \mathrm{gm}$ of specimen powder with the $200 \mathrm{ml}$ of absolute ethanol (rate 1:4 weight: size), shaking the mixture to break down plant cell walls and leave it in the refrigerator for 24 hours for the soaking. It was filtrated by several layers of medical gauze and repeated again by Buchner funnel using whatman papers No.1 to get rid of the non-crushed parts and fibers to obtain plant extract raw liquid which put them in a Rotary vacuum evaporator at the temperature of not more than $40^{\circ}$ as it works on the basis evaporation under rarefied pressure. Extracted output was placed in Shaker incubator at a temperature of $25-30^{\circ}$. Dried extract was saved freeze in airtight containers and labeled till in use (Grand et al, 1988).

\section{Glycoside Extraction:}

Glycosides extracted by adding $10 \mathrm{gm}$ of plant powder to $100 \mathrm{ml}$ of ethanol (80\%) move the mixture and leave it in the refrigerator for 24 hours for the soaking. The extraction was concentrated to $1 / 3$ it sizes by Rotary vacuum evaporator then added $50 \mathrm{ml}$ of Ether and $5 \mathrm{ml}$ of Lead acetate (0.3 molarity), in separating funnel with shaking and has withdrawn aquifer. This step was repeated three times and dried the drawn water layer at a temperature of $30^{\circ}$ until fully dry. (Ukida, et al, 2006)

\section{Alkaloids Detection:}

The method of (Fahmy, 1933) was followed by boiling $10 \mathrm{gm}$ of plant powder with $50 \mathrm{ml}$ of distilled water acidified hydrochloric acid $4 \%$, then filtrated after the solution was cooled, the amount $0.5 \mathrm{ml}$ of filtrate was tested in a test tube with each of the following reagents: 1- Meyer's reagents (white sediment)

2 - Wagner's reagents (brown sediment)

\section{Saponins Detection:}

The aqueous solution of plant specimens strongly shacked in the tube test, evidenced by the presence of saponins emergence of dense foam remain for a long time (Al-Ani, 1998). 


\section{Effect of Extracts of Eruca sativa Mill. on the Growth Inhibition of} Some Fungal Species

\section{Sirwan Hassan Salih and Mostafa Qahtan Mosataf}

\section{Resins Detection:}

Mixing $10 \mathrm{ml}$ of plant extract with the $20 \mathrm{ml}$ of distilled water acidified hydrochloric acid $\mathrm{HCl}$ $4 \%$, evidenced by the existence of resins emergence of turbidity in it. (Newall et al., 1996).

\section{Phenol Detection:}

Adding $3 \mathrm{ml}$ of aqueous plants extract to $2 \mathrm{ml}$ of ferric chloride solution $\mathrm{FeCl} 3$, the appearance of a bluish-green color evidence of the presence of phenolic compounds (Harborne, 1973).

\section{Tannins Detection:}

This step was conducted by boiling $10 \mathrm{gm}$ of plant powder in $50 \mathrm{ml}$ of distilled water, then filtrated the solution and leave to cool, the solution was divided into two equal parts, few drops of lead acetate $1 \%$ solution was added to one part, as evidenced by the existence of tannins the emergence of gelatinous precipitate and two drops of ferric chloride solution $1 \%$ was added to the other part, as it indicates the emergence of bluish green color to the presence of tannins (Al-Dalali and Hakim, 1987).

\section{Glycosides Detection:}

The detection was carried out by mixing two equal parts of the Fehling's reagent with aqueous plant extracts, placed it in boiling water bath for 10 minutes, and evidenced by a positive test by the appearance of red sediment and is evidence of the presence of sugars, to insure of this result has been added $1 \mathrm{ml}$ of water plant extracts to $5 \mathrm{ml}$ of Benedict's reagent as it confirms the emergence of red sediment on the presence of sugars, while the blue color appearance indicates to absence of sugars (Al-Shaikhli et al., 1993).

Table (1) Results of the chemical detection for effective materials of $E$. sativa

\begin{tabular}{|c|c|c|c|c|c|c|}
\hline Effective Material & Alkaloids & Saponins & Tannins & Glycosides & Resins & Phenols \\
\hline Detection results & + & + & + & + & + & + \\
\hline
\end{tabular}

(+) positive detection 


\section{Effect of Extracts of Eruca sativa Mill. on the Growth Inhibition of} Some Fungal Species

\section{Sirwan Hassan Salih and Mostafa Qahtan Mosataf}

\section{Effectiveness of anti-fungal}

The effective of the aqueous and alcoholic extracts of the studied species on the growth of the three fungal species (A. nigar, F. oxysporium and Pencillium sp.) was investigated by using culture media (Sabroud dextrose agar) that prepared in accordance to the manufacturer instructions, to prepare the petri dishes for effectiveness testing the agar diffusion method was used by drilling for observing the fungus sensitivity towards plant extracts at the concentrations of $(10,20,40$ and $100 \mathrm{mg} / \mathrm{ml})$ as it drilled by piercing sterile cork with diameter of $3 \mathrm{~mm}$ to drilling in the sabroud dextrose agar and the dishes was inoculated by fungal species, the extracts concentrations was placed in the drills with three replicates for each concentration and the dishes incubated at a temperature of $25^{\circ}$ for 7 days, the results was recorded by measuring the diameter of inhibition area $(\mathrm{mm})$.

\section{Results and Discussion}

The results indicated to positive detection whereas the studied plant was contained on all the detected materials (phenols, resins, tannins, saponin, alkaloids and glycosides) table (1). It seemed the effectiveness of the aqueous extracts of the plant with concentrations $(10,20,40$ and $100 \mathrm{mg} / \mathrm{ml}$ ) in the inhibition of two fungi species Pencillium and F. oxysporium, compared to the control differently table (2), as it showed the concentration of $100 \mathrm{mg} / \mathrm{ml}$ with highest effective inhibition compared to the others and then the concentration of $20 \mathrm{mg} / \mathrm{ml}$, while concentrations of 10 and $40 \mathrm{mg} / \mathrm{ml}$ are the least effective in the inhibition of Pencillium. As well as the aqueous extract with concentrations of 20,40 and $100 \mathrm{mg} / \mathrm{ml}$ had its inhibitory activity against the $F$. oxysporium than controls and the concentrations of 40 and $100 \mathrm{mg} / \mathrm{ml}$ have shown the higher inhibitory effectiveness in the inhibition of fungus compared to concentration of $10 \mathrm{mg} / \mathrm{ml}$, which was less effective than concentrations above, as it turns out aqueous extracts showed no inhibitory effective against $A$. nigar than controls. Figure (1)

The results of the current study also revealed that alcoholic extracts of this plant was ineffective in the inhibition of studied fungus spp. compared to the control (Table 3). The glycosides extracts with concentrations of $(10,20,40$ and $100 \mathrm{mg} / \mathrm{ml})$ has been shown effective in the 
Effect of Extracts of Eruca sativa Mill. on the Growth Inhibition of Some Fungal Species

Sirwan Hassan Salih and Mostafa Qahtan Mosataf

inhibition of both of Pencillium sp. and F. oxysporium variously compared to the control (table 4), the concentration of $20 \mathrm{mg} / \mathrm{ml}$ seemed inhibitory effective against the species Pencillium that higher than the concentration $10 \mathrm{mg} / \mathrm{ml}$.

Table (2) inhibitory effectiveness of aqueous extracts against studied fungal species

\begin{tabular}{|c|c|c|c|}
\hline \multicolumn{2}{|l|}{ fungi } & \multicolumn{3}{|c|}{ Diameter of inhibition area $(\mathrm{mm})$} \\
\cline { 2 - 4 } & Pencillium & A. nigar & F. oxysporium \\
\hline concentration $(\mathrm{mg} / \mathrm{ml})$ & 3 & 0 & 0 \\
\hline 10 & 4 & 0 & 1.66 \\
\hline 20 & 3.33 & 0 & 2.33 \\
\hline 40 & 6 & 0 & 2.33 \\
\hline 100 & 0 & 0 & 0 \\
\hline Control & & & \\
\hline
\end{tabular}

Table (3) inhibitory effectiveness of alcoholic extracts against studied fungal species

\begin{tabular}{|c|c|c|c|}
\hline \multicolumn{2}{|l|}{ fungi } & \multicolumn{3}{|c|}{ Diameter of inhibition area $(\mathrm{mm})$} \\
\cline { 2 - 4 } concentration $(\mathrm{mg} / \mathrm{ml})$ & Pencillium & A. nigar & F. oxysporium \\
\hline 10 & 0 & 0 & 0 \\
\hline 20 & 0 & 0 & 0 \\
\hline 40 & 0 & 0 & 0 \\
\hline 100 & 0 & 0 & 0 \\
\hline Control & 0 & 0 & 0 \\
\hline
\end{tabular}

Table (4) inhibitory effectiveness of glycosides extracts against studied fungal species

\begin{tabular}{|c|c|c|c|}
\hline \multicolumn{1}{|l|}{ fungi } & \multicolumn{3}{|c|}{ Diameter of inhibition area $(\mathrm{mm})$} \\
\cline { 2 - 4 } concentration $(\mathrm{mg} / \mathrm{ml})$ & Pencillium & A. nigar & F. oxysporium \\
\hline 10 & 1.33 & 0 & 1.33 \\
\hline 20 & 4 & 0 & 0 \\
\hline 40 & 0 & 0 & 0 \\
\hline 100 & 0 & 0 & 0 \\
\hline Control & 0 & 0 & 0 \\
\hline
\end{tabular}


Effect of Extracts of Eruca sativa Mill. on the Growth Inhibition of Some Fungal Species

Sirwan Hassan Salih and Mostafa Qahtan Mosataf

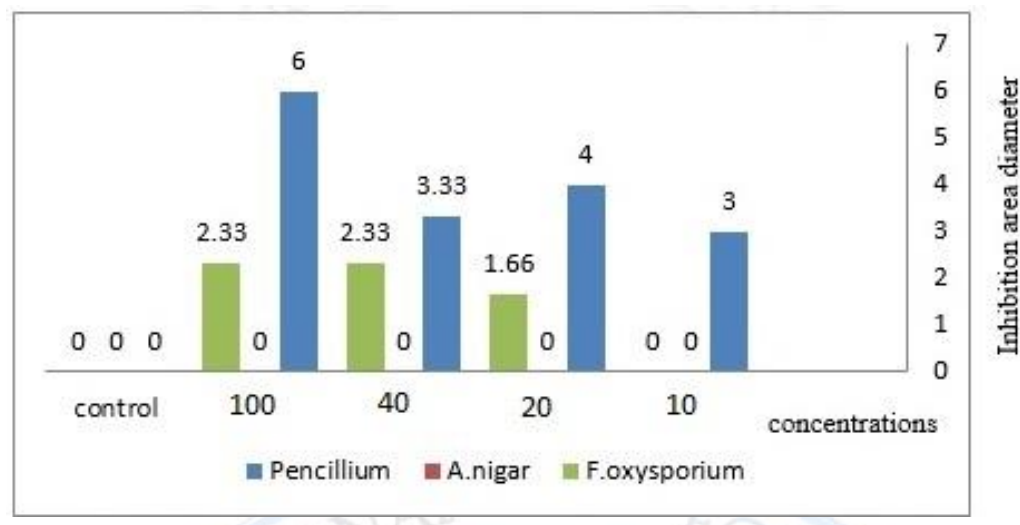

Figure 1: inhibitory effectiveness of aqueous extracts of the $E$. sativa against studied fungal species

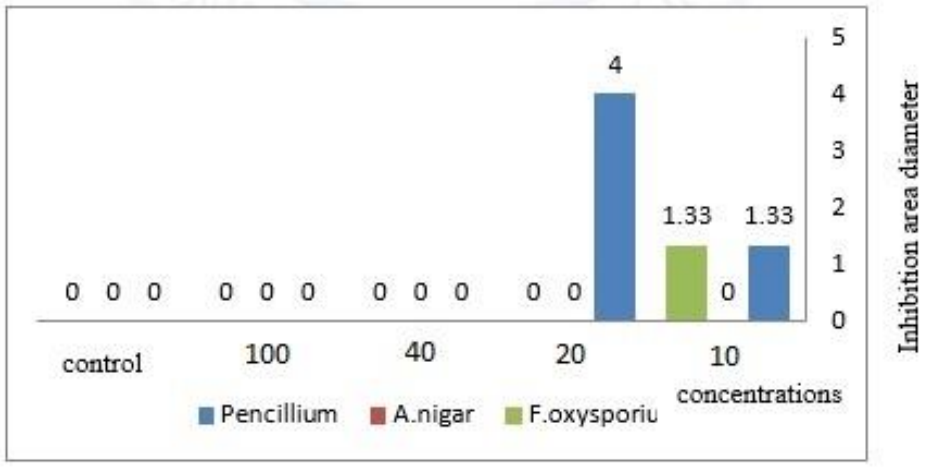

Figure 2: inhibitory effectiveness of glycosides extracts of the $E$. sativa against studied

\section{fungal species}

The results also showed that the concentration of $10 \mathrm{mg} / \mathrm{ml}$ was only effective in the inhibition of $F$. oxysporium compared to control and to other concentrations, as it is shown in table (4), the ineffectiveness of glycosides extracts with concentration of $(10,20,40$ and $100 \mathrm{mg} / \mathrm{ml})$ for the inhibition of $A$. nigar than controls figure (2). The leaves of this plant contain glycosides and sulfur glycosides which affect the cells proteins and thus inhibit the cell activity inside the cell (Kyung and Lee, 2001) in addition to the alkaloids, that stop manufacture of nucleic acids in living cell through the inhibiting DNA Gyrase enzyme (Al-Palani, 2003). The saponine also affect the removal of living cells membranes (Qutib,1979) and the tannins are working on the inhibition of enzymes and carrier proteins in the cell membrane (Cowon, 2000), the mechanical 


\section{Effect of Extracts of Eruca sativa Mill. on the Growth Inhibition of} Some Fungal Species

\section{Sirwan Hassan Salih and Mostafa Qahtan Mosataf}

action of glycosides and sulfur glycosides include the interaction with a group (-SH) in cells, which presence in cells proteins' that interact with amino acid cysteine and likewise make bisulfur bond (S-S) and the sulfur group (SH-) has a special stimulators multiply the cells where the sulfur compounds are working on break down this group and consequently will discourage biological activity and replication in the cell (Kyung and Lee, 2001)

\section{Conclusions}

This study concluded that the aqueous extracts of the Eruca sativa with concentrations (10, 20, 40 and $100 \mathrm{mg} / \mathrm{ml}$ ) has effectiveness in the inhibition of two fungal species Pencillium and $F$. oxysporium, which the concentration of $20,100 \mathrm{mg} / \mathrm{ml}$ with highest effective inhibition compared to the others, while the concentrations of 10 and $40 \mathrm{mg} / \mathrm{ml}$ are the least effective in the inhibition of Pencillium, the alcoholic extracts was ineffective in the inhibition of studied fungus species, whilst the concentration of $20 \mathrm{mg} / \mathrm{ml}$ of glycosides extracts seemed inhibitory effective against the species Pencillium that higher than the concentration of $10 \mathrm{mg} / \mathrm{ml}$. and the concentration of $10 \mathrm{mg} / \mathrm{ml}$ was only effective in the inhibition of $F$. oxysporium, however the growth of the species $A$. niger was not affected by all concentrations of all extracts.

\section{Acknowledgement}

The authors would like to thank the Head and staff of Biology department in Faculty of Education (Garmian University) and college of Education (Tekret University) for their helping and providing laboratories

\section{References}

1. Abdou, I. A.; Abou-Zeid A. A.; El-Sherbeeny, M. R. and Abo-El-Gheat, Z. H. (2005). Antimicrobial activities of Allium sativum L. , Allium cepa L., Raphanus sativus L., Capsicum frutescens L., Eruca sativa Mill. and Allium kurrat L. on bacteria, Plant Foods Human Nutrition, 22 (1): pp: 22-29.

2. Al-Ani, Hilal; A. J. (1998). Study of local black bean components Nigella sativa extracts and the effect of its extracts on some of Microorganisms. Master Thesis, college of Science, University of Mustansiriya, Iraq 


\section{Effect of Extracts of Eruca sativa Mill. on the Growth Inhibition of Some Fungal Species}

\section{Sirwan Hassan Salih and Mostafa Qahtan Mosataf}

3. Al-Dalali, B. K. and Al-Hakim, S. H. (1987). Food analysis, dar al-kutib, Mosul University. Iraq.

4. Al-Joboory, A. and Al-Rawi, M. (1994). Natural pharmacology.1st ed. Baghdad, dar AlHuriah.

5. Al-Palani and Rashid, M. (2003). Effect of the crude plant extracts and vasisin alkaloid of shrubby Antirrhinum majus L. on some of pathogenic prions.

6. Al-Shaikhly, M. A. S. et al. (1993). Practical Biochemistry, Mustansiriya University. Iraq.

7. Angiosperm Phylogeny Group (2009). "An update of the Angiosperm Phylogeny Group classification for the orders and families of flowering plants: APG III". Botanical Journal of the Linnaean Society 161 (2): pp: 105-121.

8. Cowon, M. M. (2000). Plant product as antimicrobial agents. Clinical Microbiology Reviews, 15: pp: 100-110.

9. El-Gengaihi, S. E.; Salem, A.; Bashandi, S. A.; Ibrahim, N. A. and El-Hamid, S. R . (2004). Hyperlipidemic effect of some vegetable oils in rats. Food Agri. and Env., 2 (2): pp: 8893.

10. Evans, W. C. (1999). Tease and Evans Pharmaconosy. 14th ed WB Saunders company Ltd; London.

11. Fahmy, I. R. (1933). Constituents of plant crude drugs . 1st ed,. Poul Barbey . Cairo.

12. Grand, A ., Verpoort, R., Wonder gem, P.A . and Pousset, J.L.(1988). Anti-infection

13. Harborne, J.B., and Baxter, H. (1993). Phytochemical Dictionary. A hand book of Bioactive compound from plants. Taylor and Francis, London.

14. Holt, J. G.; Krieg, N. R.; Sneath, P. H. A.; Staley, J. T. and Williams, S. T. (1994). Gramnegative aerobic microaerophilie rods and cocci. In Bergeys manual of determinative bacteriology. 9th ed. Williams and Wilkins, U.S.A. pp: 71-100.

15. Hussein, F. T. K. (1985). Medicinal plants in Libya. Al-Fatih university. Arab Encyclopedia House, Libya. 1 st print. Libya.

16. Kochhar, S. L. (1981). Economic Botany in the tropics. Elegant printers, New Delhi-India. pp: $153-158$. 
Effect of Extracts of Eruca sativa Mill. on the Growth Inhibition of Some Fungal Species

\section{Sirwan Hassan Salih and Mostafa Qahtan Mosataf}

17. Kyung, K. H. and Lee,Y. C. (2001). Antimicrobial activity of sulfur compound derived from some S-Alkyl-cysteine sulfoxides and Allium and Brassica food Rev. Int.17(2): pp: $190-198$.

18. Merza, H. H.; Hussein, H. H.; Tarawneh, K. A. and Shakhanbe, hJ. M. (2000). Effects of applications of some medicinal plant extracts used in Jordan on social aggression as well as testicular and prenuptial gland structures in male mice, Pakistan J. Biol. Sci., 3 (3): pp: 398-402.

19. Mohammed, H .C. and A. Rafiq. (2009). Investigating possibility of using least desirable edible oil of Eruca sativa Mill. in bio diesel production, Pakistan J. Bot., 41 (1): pp: 481-487.

20. Newall, C. A.; Anderson, L. A. and Phillip son, J. D. (1996). Herbal Medicines . A guide for Health care Professionals . The Pharmaceutical Press. London . pp:69-70.

21. phytotherapies of tree-Sarannah Senegal (west-Africa). 11-Antimicrobial activity of 33 species. J. Ethanopharmacol., 22: pp. 25-31.

22. Qutib and Fawzi, H. (1979). Medicinal plants cultivation and their components, Dar Al Arabia for the book Libya - Tunisia.

23. Roaiha and Amin, (1983). Herbal medicine in a scientific way include modern and ancient medicine, 7 th edition. Dar al-qalam. Beirut. Lebanon .

24. Ukida, M.; Akihisa, T.; Yasukawa, K.; Tokuda, H.; Suzuki, T. and Kimura, Y.2006.Antiin flammatory, anti- tumor promoting and cytotoxic activities of constituents of Marigold (Calendula aofficinallis) flowers. J. Nat. Prod., 96: pp: 1692- 1696.

25. Yaniv, Z. (1997). Traditions Uses and Research on Rocket in Palestine. In Rocket: A Mediterranean crop for the world. Report of a workshop, 13-14. December 1996, Legnaro, Italy; Pignone, D., Padulosi, S., Eds.; IPGRI: Rome. pp: 76-80. 